\title{
TELLING MILLER'S TALE: A REPLY TO DAVID YASSKY
}

\author{
BRANNON P. DENNING* AND GLENN H. REYNOLDS**
}

\section{INTRODUCTION}

Only in recent years ${ }^{1}$ have those opposed to the individual rights interpretation of the Second Amendment, which one of us dubbed the "Standard Model," come forth with theories attempting to harmonize text, history, and structure to show that the Amendment is the Constitution's version of Oakland-that there is no "there" there. Earlier "theories" had tended to be merely makeweight arguments whose implications were never probed in depth by their proponents. ${ }^{2}$ A recent article by Professor David Yassky suggests that there is a segment of legal academia that dissents from the Standard Model and has started to generate alternatives to the Standard Model. ${ }^{3}$ In this brief essay, we critique that part of Yassky's theory dismissing United States $v$. Miller ${ }^{4}$ as providing the basis for an individual rights interpretation of the Second Amendment.

In his provocative response to the Standard Model, Yassky argues that, if the dramatic changes to our constitutional regime since the time of the Amendment's drafting are taken into account, the Standard Model proves inadequate. 5 One question that Yassky addresses is why the Supreme Court has continued to underenforce the Amendment, treating it as a "constitutional pariah, barred from associating with other 'high caste' civil liberties that [the Court] has labored to protect ${ }^{\prime \prime}$ in the years since the so-called Constitutional Revolution of 1937. Yassky provides this answer:

The Supreme Court of the late 1930s and 1940s saw [civil liberties like freedom of speech] as both ameliorating dangers of the new administrative state, while also being rooted in key New Deal themes [such as Roosevelt's famous "Four Freedoms"]; ac-

Copyright (C) 2002 by Brannon P. Denning and Glenn H. Reynolds

This article is also available at http://www.law.duke.edu/journals/65LCPDenning.

* Assistant Professor of Law, Southern Illinois University, Carbondale.

** Professor of Law, University of Tennessee, Knoxville.

1. An obvious exception to this general statement is the work of David Williams. See infra note 13.

2. See infra note 14 (discussing the work of Dennis Henigan).

3. David Yassky, The Second Amendment: Structure, History, and Constitutional Change, 99 MICH. L. REV. 588 (2000).

4. 307 U.S. 174 (1939).

5. Yassky, supra note 3, at 518-610, 629-44.

6. Brannon P. Denning, The Second Amendment as an Underenforced Constitutional Norm, 21 HARV. J.L. \& PUB. POL'Y 719, 791 (1998). 
cordingly it revitalized the First Amendment. The court could not, however, envision a similar role for the right to keep and bear arms.

This, Yassky argues, is key to understanding what he terms "the failure of the courts" to enforce the Amendment and accounts for its virtual repeal at all levels of the federal judiciary. ${ }^{8}$ Indicative of this failure is the United States Supreme Court's only case this century squarely addressing the Second Amendment, United States v. Miller.' Yassky, however, devotes only a few pages to Miller, a decision he defends only with the observation that the opinion "says very little." 10 What he does say is that "the Miller opinion ... plainly rule[s] out" what he terms "the revisionists' Libertarian Approach" to the Second Amendment. ${ }^{11}$

Yassky's reading of Miller is mistaken. When the decision is read closely and the arguments available (and not available) to the Court are taken into account, the decision is best understood as leaving open the opportunity for courts to adopt the Standard Model reading of the Second Amendment. What Miller plainly does not do is deny that an individual's right to keep and bear arms is protected by the Second Amendment - the holding ascribed to it by most federal courts since 1939. ${ }^{12}$ Yassky's error on this subject requires correction.

At the outset, we admit that we are focusing on a small part of Yassky's argument, but we think that this focus on Miller is justifiable on several grounds. First, any subsequent Supreme Court interpretation of the Second Amendment will have to take Miller into account. It is Miller, after all, that lower courts have cited to maintain that the Second Amendment did not create an individual right to keep and bear arms. If Yassky is correct and the Standard Model or "Libertarian Approach" finds no support there, then that would likely end the

7. Yassky, supra note 3, at 663.

8. Id. at 665 .

9. 307 U.S. 174 (1939).

10. Yassky, supra note 3, at 665 ("We are nearly at the end of this Article, and I have said very little about the Supreme Court's opinion in Miller. The reason is that the opinion itself says very little.").

11. Id. at 666. The revisionists to whom Yassky refers are those scholars who subscribe to the "Standard Model" and so think that the Second Amendment protects some individual right to keep and bear arms. See id. at 590-91 \& nn.3-10 (describing the revisionist approach and identifying legal scholars who have adopted or defended it). Yassky defines the "Libertarian Approach" as follows:

[I]t sees the right to keep and bear arms as akin to the First Amendment rights of free speech and conscience-a fundamental aspect of individual autonomy the infringement of which is per se tyrannical.... [A]t its core is the ... interest in self-defense. The notion is that a government that forces its citizens to remain defenseless against bullies and predators is no better than a government that itself subjects its citizens to unreasonable searches and seizures. Id. at 615 (footnotes omitted).

12. See, e.g., Brannon P. Denning, Can the Simple Cite Be Trusted?: Lower Court Interpretations of United States v. Miller and the Second Amendment, 26 CUMB. L. REV. 961, 981-98 (1996) (citing and discussing examples of lower court decisions holding that the Second Amendment did not guarantee an individual right). But see United States v. Emerson, 270 F.3d 203, 260 (5 $5^{\text {th }}$ Cir. 2001) (concluding that the Second Amendment does not guarantee an individual right). In the interest of full disclosure, one of us (Reynolds) signed an amicus brief supporting the appellee in the Emerson case; the other (Denning) wrote, pro bono, an amicus brief in support of the appellee making arguments about Miller similar to those made in this article. Professor Yassky also participated as amicus curiae in the Emerson case, authoring a brief supporting the United States. 
matter for courts. They would have no need to resort to Yassky's elaborate arguments that dramatic shifts in military posture, begun in the nineteenth century and completed in the twentieth, from state militia to a federally controlled, professional military apparatus constitute a temporally extended "constitutional moment" that has drained the Second Amendment of enforceable content. ${ }^{13}$

On the other hand, if, as we argue, Miller does not close the door on the enforcement of the Second Amendment, then that, too, is important. While a Supreme Court endorsement of the Standard Model does not settle the scope of the right, it does move the debate beyond the point at which it is presently stalled: the question whether it guarantees any individual right at all. ${ }^{14} \mathrm{~A}$ judicial victory for the Standard Model would also be a rebuke to lower courts that have consistently over-read Miller. ${ }^{15}$ Recognizing an individual right would then, of necessity, move the debate to questions about the scope of the right: the legitimacy of the government's interest in controlling individual possession of certain types of weapons, the reasonableness of particular gun control proposals, the availability of less restrictive alternatives, and the like. All are questions that form the warp and woof of ordinary constitutional law. ${ }^{16}$ That we are

13. Yassky, supra note 3, at 667.

[T] he most important reason courts have read Miller the way they have is because they sense the importance of the changes in constitutional structure that I have tried to examine in this Article.... The Founders designed the Constitution in the belief that state militias were preferable to a federal army; after the Civil War, this belief could no longer serve as a fundamental constitutional premise... . The purpose of the Second Amendment had been to fortify the Militia Clauses; now that these provisions were a dead letter, the Second Amendment was adrift.

Id. Yassky's theoretical construct, as he acknowledges, draws on Bruce Ackerman's theory of constitutional change. See 1 BRUCE ACKERMAN, We the PeOPle: Foundations (1992); 2 BruCE ACKERMAN, We THE PEOPLE: TRANSFORMATIONS (1998). The consequences of these constitutional changes, especially the decline of the citizen-soldier's role in a state militia, on judicial enforcement of the Second Amendment are reminiscent of David Williams's arguments. See David C. Williams, Civic Republicanism and the Citizen Militia: The Terrifying Second Amendment, 101 YALE L.J. 551 (1991).

14. Yassky acknowledges the "collective rights" argument-the argument that the Second Amendment protects only the right of an unspecified, aggregate "people" to engage in armed defense of the state, or that the right merely guarantees states the right to maintain an armed militia-only to dismiss it as a "red herring," though he does concede that some courts have incorrectly employed that argument to deny individuals standing to raise Second Amendment claims. See Yassky, supra note 3, at $613-14 \&$ n. 106. That argument is hardly one of the Standard Modelers' own making. If the collective rights argument is a straw man, it was one erected with loving care by those like Dennis Henigan (whom Yassky elsewhere cites approvingly) and certain federal courts, as a makeweight or way to forestall debate on more important questions, such as the scope of the Second Amendment right. See Dennis A. Henigan, Arms, Anarchy and the Second Amendment, 26 VAL. U. L. REV. 107, 119 (1991) ("The purpose of the [Second] Amendment was to affirm the people's right to keep and bear arms as a state militia, against the possibility of the federal government's hostility, or apathy, toward the militia."); but see Glenn Harlan Reynolds \& Don B. Kates, The Second Amendment and States' Rights: A Thought Experiment, 36 WM. \& MARY L. REV. 1737 (1995) (describing possible unintended consequences of adopting such an interpretation).

15. See infra notes 52-53; see also Denning, supra note 12, at 981-98 (discussing lower court cases interpreting the Second Amendment).

16. See Dan Polsby, Treating the Second Amendment Like Ordinary Constitutional Law, REASON, Mar. 1996, at 32, 33.

For the legal profession, constitutional text, history, precedent and matters of expediency are all important, and no one provision of the Constitution is to be seized upon without due recognition of its context in the Constitution as a whole, and for the strands of doctrine that the 
still mired in questions of the Second Amendment's applicability to individuals suggests how primitive our Second Amendment "jurisprudence" is. No one seriously makes arguments to the courts, for example, that the First Amendment protects a "collective right" to the free exchange of political ideas and was never intended to cover the myriad forms of individual expressive activity that find protection in the Supreme Court's decisions. ${ }^{17}$

\section{II}

\section{THE SUPREME COURT'S HOLDING IN UNITED STATES V. MILLER}

United States v. Miller arose as a result of an appeal taken by the United States Government to the Supreme Court following the dismissal of an indictment against two Arkansas men accused of possessing a sawed-off shotgun in violation of the National Firearms Act of $1934{ }^{18}$ The U.S. District Court for the Western District of Arkansas had quashed the indictment, finding that the National Firearms Act "offend[ed] the inhibition of the Second Amendment to the Constitution." 19 The government appealed directly to the United States Supreme Court. The government was the only party that filed a brief with the Court and was the sole party appearing at oral argument.

The Supreme Court reversed the District Court, but in doing so, it avoided any sweeping statements regarding the scope of the Second Amendment. It simply held that

[i]n the absence of any evidence tending to show that possession or use of a [sawed-off shotgun] at this time has some reasonable relationship to the preservation or efficiency of a well regulated militia, we cannot say that the Second Amendment guarantees the right to keep and bear such an instrument. Certainly it is not within judicial notice that this weapon is any part of the ordinary military equipment or that its use could contribute to the common defense. ${ }^{20}$

Implicit in the holding is that if the defendants had made such a showing, the Court might have struck down the provision in question. Moreover, there seemed no question that the defendants as individuals were competent to raise the Second Amendment as a defense. If a collective or states' rights view were adopted, the Court could have reversed the District Court on the ground that the individual defendants - who were quite obviously not "states," and who apparently were not members of any formal or informal "well regulated militia"-

Supreme Court has elaborated over the years to translate the words of the document into the actions of the government... This is a game in which the Second Amendment has never Id. really played.

17. Or at least courts have not bought into them. Even "commercial speech," which arguably has very little to do with facilitating civic discussions among citizens, now receives First Amendment protection that is virtually indistinguishable from that afforded purely "political" speech. E.g., Lorillard Tobacco Co. v. Reilly, 533 U.S. 525, 564-68 (2001) (concluding that state restrictions on tobacco advertising violate the First Amendment).

18. Miller, 307 U.S. at 174 (citing 48 Stat. 1236, § 6 (1934)).

19. United States v. Miller, 26 F. Supp. 1002, 1003 (W.D. Ark. 1939), rev'd, 307 U.S. 174 (1939).

20. Miller, 307 U.S. at 178. 
did not have standing to invoke the Second Amendment's protections. ${ }^{21}$ That it did not question the defendants' standing strongly suggests that the Court did not adopt a "states' rights" or "collective rights" interpretation of the Second Amendment. ${ }^{22}$

While Justice McReynolds described the "obvious purpose" of the Second Amendment as assuring the continuing effectiveness of the militia, ${ }^{23}$ and wrote that the Amendment "must be interpreted and applied with that end in view," he also noted that, at the time of the Framing, militias were made up of individuals_-"all males physically capable of acting in concert for the common defense ${ }^{25}$ who often supplied their own weapons. ${ }^{26}$ Militia members are, in Justice McReynolds's words, "civilians primarily, soldiers on occasion." ${ }^{27}$ More importantly, they are, as McReynolds recognized, individuals. Securing for individuals the right to keep and bear arms enabled them to serve as members of militias, thus providing the primary means of "assur[ing] the continuation and render[ing] possible the effectiveness of" militias. ${ }^{28}$ As Thomas Cooley noted, " $[\mathrm{t}]$ he alternative to a standing army is a 'well-regulated militia'; but this cannot exist unless the people are trained to bearing arms.",29

III

\section{THE MILLER COURT AND THE GOVERnMENT'S ARGUMENT}

Further supporting the argument that the Miller Court implicitly adopted an individual rights interpretation of the Second Amendment is the fact that the Court rejected the collective rights argument made by the United States Government in its brief. ${ }^{30}$

The government claimed that "the very language of the Second Amendment discloses that this right has reference only to the keeping and bearing of arms by the people as members of the state militia or other similar military organiza-

21. E.g., Tenn. Elec. Power Co. v. Tenn. Valley Auth., 306 U.S. 118 (1939) (holding that an electric company could not challenge TVA because it lacked standing); Alabama Power Co. v. Ickes, 302 U.S. 464 (1938) (same). Yassky concedes that "Miller is ... inconsistent with the strong version of the collective rights approach which turns the Second Amendment into a standing requirement. ..." Yassky, supra note 3 , at 667 n. 328 .

22. The Court's rejection of a "states' rights" view of the Second Amendment is confirmed by the Court's rejection of such arguments made by the federal government in its brief, described below. See infra Part III.

23. Miller, 307 U.S. at 178.

24. Id.

25. Id. at 179 .

26. $I d$.

27. Id. at $178-79$.

28. Id. at 178 .

29. 1 Thomas M. CoOley, Constitutional Limitations 729 (8th ed. 1927); see also William Van Alstyne, The Second Amendment and the Personal Right to Arms, 43 DUKE L.J. 1236, 1244 (1994) (writing that the Second Amendment "expressly embraces" the right to keep and bear arms and "erects the very scaffolding of a free state upon that guarantee"; "[t]he militia to be well-regulated is a militia to be drawn from ... people with a right to keep and bear arms ... rather than from some other source (i.e., from people without rights to keep and bear arms)").

30. Brief of the United States at 4-5, United States v. Miller, 307 U.S. 174 (1939) (No. 696). 
tion provided for by law." ${ }^{31}$ The government further argued that the Second Amendment "gave sanction only to the arming of the people as a body to defend their rights against tyrannical and unprincipled rulers" and "did not permit the keeping of arms for purposes of private defense." ${ }^{32}$ The reference to a "well regulated militia" that precedes the Second Amendment, it maintained, "indicates that the right to keep and bear arms is not one which may be utilized for private purposes but only one which exists where the arms are borne in the militia or some other military organization provided for by law and intended for the protection of the state.",33

The Court made no direct mention of these arguments in its opinion, ${ }^{34}$ instead, it partially adopted another of the government's arguments. Assuming arguendo that the Second Amendment protects an individual right to keep and bear arms, the government argued, the only arms protected were those suitable to military purposes, as opposed to weapons-like sawed-off shotguns-that "constitute the arsenal of the "public enemy' and the 'gangster" and that the National Firearms Act was intended to regulate..$^{35}$ Even here the Court handed the government only half a loaf. The Miller Court said merely that it was presented with no evidence of, and could not take judicial notice of, a sawed-off shotgun's military utility. ${ }^{36}$

It is true that "[ $\mathrm{t}]$ he Court [in Miller] did not ... attempt to define, or otherwise construe, the substantive right protected by the Second Amendment." ${ }^{37}$ It is also true, however, that Miller could be read to have adopted the Standard Model: (1) by not reversing the lower court's decision on the ground that the defendants lacked standing; and (2) by rejecting the government's arguments that the Second Amendment protected only a collective right. ${ }^{38}$

IV

\section{PROFESSOR YASSKY'S ARGUMENTS FOR A NARROW READING OF MILLER}

In his article, Yassky states that "the Miller opinion does plainly rule out the revisionists' Libertarian Approach." ${ }^{39}$ Despite the certitude with which he

31. $I d$.

32. Id. at 12. The Government's assertion that a purpose of the Second Amendment was to enable "the People" to rise up against a tyrannical federal government would no doubt surprise those like Dennis Henigan and Michael Bellesiles, who have excoriated such claims as, at best, irresponsible. E.g., Michael A. Bellesiles, Suicide Pact: New Readings of the Second Amendment, 16 CONST. CommenT. 247 (1999); Henigan, supra note 11.

33. Brief of the United States at 15, Miller (No. 696).

34. It is possible that Justice McReynolds' reference to the universal membership of Framing-era militias and the private ownership of arms by militia members was an indirect rebuttal of the Government's arguments that the protections of the Second Amendment should only extend to the militia collectively. Miller, 307 U.S. at 179-82.

35. Brief of the United States at 18, 20, Miller (No. 696).

36. Miller, 307 U.S. at 178.

37. Printz v. United States, 521 U.S. 898, 938 n.1 (1997) (Thomas, J., concurring).

38. Miller, 307 U.S. at 178 (holding only that the Court was presented with no evidence of, and could not take judicial notice of, sawed-off shotgun's military utility).

39. Yassky, supra note 3, at 666. 
makes this claim, the evidence he posits in support of it is meager, and his arguments belie an unfamiliarity with those put forth by the government in Miller. First, he claims that "revisionists read Miller as holding merely that certain weapons are beyond the reach of Second Amendment protection" ${ }^{40}$ based on certain language, such as the Court's refusal to take judicial notice of a sawedoff shotgun's military utility. ${ }^{41}$ This is a problem, he argues, because the National Firearms Act also regulated machine guns, which, he claims, "were standard-issue military equipment in 1939, as they are today." 42 Yassky explains that, "if we read Miller as resting on the premise that short-barreled shotguns are not 'military equipment,' the National Firearms Act's regulation of machine guns is presumably unconstitutional." ${ }^{43}$ Even allowing for the fact that "judges are supposed to limit themselves to the case at hand," he is incredulous at the possibility that "the Court would have upheld one part of the statute by formulating a rule that immediately and obviously invalidates another part of the very same statute without even alluding to the tension." ${ }^{44}$

His conclusion is flawed for several reasons. First, the government itself proffered the "military utility" argument. ${ }^{45}$ If the government failed to note the tension Yassky sees, then why should it bother the Court? Second, Yassky's conclusion is based on the erroneous premise that Miller was indeed establishing a rule, or that, if it did, that that rule "immediately and obviously" invalidated anything. Recall that the Court said only that it could not take "judicial notice" of the fact that the shotgun was part of standard military equipment or somehow militarily useful. ${ }^{47}$ The Court's statement was simply an acknowledgment of the fact that it had seen no conclusive evidence one way or the other.

40. Id.

41. Miller, 307 U.S. at 178.

42. Yassky, supra note 3, at 666. Actually, it is incorrect to say that machine guns were "standardissue" military equipment in 1939. The standard-issue infantry weapon in the United States Army at that time would have been the M-1 Garand semi-automatic rifle adopted for use by the United States Army in 1936, and by the United States Marine Corps in 1940. See Background Information on the United States Rifle Caliber .30 M1, available at http://www.wwa.com/ dvelleux/m1rifle.html (last visited Dec. 20, 2001). The M1A1 Thompson submachine gun was not ordered by the U.S. Army in large numbers until 1941. See http://www.rt66.com/ korteng/SmallArms/thompson.htm (last visited Dec. 20, 2001).

43. Yassky, supra note 3, at 666.

44. Id. Under Yassky's logic, subsequent decisions of the Supreme Court, in which the Second Amendment is mentioned among other individual rights in the Bill of Rights, would suggest that the Court, too, subscribes to the Standard Model. If it did not, why would it continue to list the right to keep and bear arms with other rights all acknowledge to be "individual"? See David B. Kopel, The Supreme Court's Thirty-five Other Second Amendment Cases: What the Supreme Court Has Said About the Second Amendment, 18 ST. LOUIS U. PUB. L. REV. 99 (1999). For Yassky's response, see David Yassky, The Sound of Silence: The Supreme Court and the Second Amendment, 18 ST. LOUIS U. PUB. L. REV. 189 (1999).

45. See supra note 35 and accompanying text (describing the government's argument that the Second Amendment protected only weapons with military utility, as opposed to those that "constitute[d] the arsenal of the 'public enemy' and the 'gangster"'). Brief of the United States at 20, Miller (No. 696).

46. Yassky, supra note 3, at 666.

47. Miller, 307 U.S. at 178. 
And how could it have? The government was the only party who appeared before the Court at oral argument, and the only party who filed a brief in the case. Assuming that the Court did intend to set a threshold requirement of military utility for Second Amendment protection, as many state courts had under analogous state constitutional provisions, ${ }^{48}$ it does not follow that the government's regulation of machine guns under the National Firearms Act would be prima facie unconstitutional. Instead, it might merely mean that, in modern $\mathrm{Su}$ preme Court parlance, government regulation of such weapons must survive strict scrutiny - the regulations must serve a compelling governmental interest and be narrowly tailored to serve that interest. Of course, since strict scrutiny has been described as "strict' in theory but fatal in fact," ${ }^{, 4}$ its application to legislation regulating private gun ownership could presage a more libertarian reading of the Second Amendment by courts-that is, an interpretation of the Amendment that is more hostile to some forms of gun control.

We cannot know what the Court would have done had sufficient evidence been presented. The Court framed its decision only in terms of information that it did not have. But it did not hold, as the government urged, ${ }^{50}$ that the Second Amendment did not protect an individual right. At the very least, Miller suggests that the Court was open to such arguments and that weapons with military utility could find protection under the Second Amendment, with the burden shifting to the government to demonstrate why its regulation of such weapons is necessary and reasonable.

Yassky further argues that a "revisionist reading of Miller has the perverse result that the deadlier a firearm is, the more likely it is to receive constitutional protection-because the military... prefers weapons that are as efficient and effective at killing as possible." ${ }^{51}$ This argument echoes the favored reductio ad absurdum of courts and anti-Standard Model scholars alike: that an individual rights reading of the Second Amendment would compel judicial protection for individual possession of nuclear weapons. ${ }^{52}$ Yassky quotes from a sixty-year-old First Circuit opinion, Cases v. United States, which speculated that Miller, taken to its logical conclusion, would require protection for individual possession of "distinctly military arms, such as machine guns, trench mortars, anti-tank or anti-aircraft guns...." ${ }^{53}$ The point, however, is a non sequitur. Recognizing the

48. E.g., Glenn H. Reynolds, The Right to Keep and Bear Arms Under the Tennessee Constitution: A Case Study in Civic Republican Thought, 61 TENN. L. REV. 647 (1994).

49. Gerald Gunther, The Supreme Court, 1971 Term-Foreword: In Search of Evolving Doctrine on a Changing Court: A Model for a Newer Equal Protection, 86 HARV. L. REV. 1, 8 (1972); but see Adarand Constructors, Inc. v. Pena, 515 U.S. 200, 237 (1995) ("we wish to dispel the notion that strict scrutiny is 'strict in theory, but fatal in fact'") (citation omitted) (internal quotation marks omitted).

50. Brief of the United States at 4-5, Miller (No. 696).

51. Yassky, supra note 3, at 666.

52. The clearest judicial expression of this fear can be found in United States v. Warin, 530 F.2d 103 (6th Cir. 1976), where the court editorialized that any interpretation of the Second Amendment that placed significant restrictions on the power of Congress to regulate the private possession of weapons "is completely irrational in this time of nuclear weapons." Warin, 530 F.2d at 106.

53. Yassky, supra note 3, at 666 (quoting Cases v. United States, 131 F.2d 916, 922 (1st Cir. 1942) (internal quotation marks omitted)). 
existence of an individual right under the Second Amendment and the articulation of the right's scope are separate issues. It does not follow from the former that a court would be obliged to countenance any individual's possession of any sort of weapon, any more than the right to free speech protects offers to bribe government officials. ${ }^{54}$

Finally, Yassky states that, if the crux of Miller is the "link between the regulated weapon and militia service," then the Second Amendment cannot "truly [be] about a personal right to arm oneself," because a sawed-off shotgun "is quite useful for self-defense-it is, in fact, a terrifying weapon-and under the Libertarian Approach, denying access to such a weapon would certainly infringe upon a Second Amendment interest." 55 First, to the extent that he suggests that those endorsing a Libertarian Approach-what we term the Standard Model-oppose any and all forms of gun control, Yassky's argument is a red herring. That is not how he initially described the Libertarian Approach in his article $^{56}$ and is not the position of Standard Modelers, whose views on the scope of permissible regulation of private ownership of firearms vary widely, but who generally accept a degree of regulation as legitimate. ${ }^{57}$ Moreover, it suggests

Incidently, it is Cases, decided in 1942, and not Miller, that is the real source of many of the sweeping propositions for which other federal courts have misleadingly cited Miller. See Denning, supra note 12 at 981-84, 989-98 (discussing Cases and its popularity with other lower courts); Denning, supra note 6, at 744-48 (same). In Cases, the First Circuit rejected a Second Amendment challenge and upheld the conviction of a defendant, a convicted felon, for possession of a firearm in violation of federal law. Cases, 131 F.2d at 917-18. In doing so, the First Circuit refused to follow Miller to the extent that the case could be read to restrict governmental regulation of any weapon for which "a reasonable relationship to the preservation or efficiency of a well-regulated militia" could be demonstrated. Id. at 922. Such a reading, coupled with the realities of modern warfare in which all weapons had potential military utility, the court argued, would mean that "the federal government would be empowered only to regulate the possession or use of [antique or obsolete] weapons. ..." Id. This, the court concluded, "is in effect to hold that the limitation of the Second Amendment is absolute." Id.

Rather than leave such questions for resolution by the Supreme Court, the Cases court upheld the conviction, despite the fact that the weapon that the defendant was convicted of possessing had military utility, since there "was no evidence that the appellant was or ever had been a member of any military organization or that his use of the weapon under the circumstances disclosed was in preparation for a military career," and assumed the defendant was "in possession of ... the firearm and ammunition simply on a frolic of his own... without any thought or intention of contributing to the efficiency of the well-regulated militia...." Id. at 923.

Cases thus introduced a "state of mind" requirement that has proved popular with subsequent courts, which have found it a convenient method for disposing of Second Amendment claims. E.g., United States v. Wright, 117 F.3d 1265, 1272 (11th Cir. 1997); United States v. Rybar, 103 F.3d 273, 286 (3rd Cir. 1996); Love v. Pepersack, 47 F.3d 120, 124 (4th Cir. 1995); United States v. Hale, 978 F.2d 1016, 1019-20 (8th Cir. 1992). Even when claimants have attempted to present evidence of membership in an unorganized militia, or otherwise attempted to meet the Cases intent requirement, courts have dismissed such evidence out of hand. E.g., Rybar, 103 F.3d at 286.

54. E.g., Glenn Harlan Reynolds, A Critical Guide to the Second Amendment, 62 TENN. L. REV. 461, 478-80, 499-504 (1995) (describing limits on weapons permitted by the Second Amendment).

55. Yassky, supra note 3, at 666-67 (footnote omitted).

56. See supra note 11 and accompanying text.

57. Compare Stephen P. Halbrook, What the Framers Intended: A Linguistic Analysis of the Right to "Bear Arms," 49 LAW \& CONTEMP. PROBS. 151, 162 (1986) (concluding that "[i]t is inconceivable that [the Framers of the Second Amendment] would have tolerated the suggestion that a free person has no right to bear arms without the permission of a state authority, much less the federal government. ...") with Don B. Kates, Jr., The Second Amendment: A Dialogue, 49 LAW \& CONTEMP. PROBS. 
that accepting the Standard Model requires elevating the personal right of selfdefense over all other competing societal claims. Early state court decisions interpreting state constitutional provisions rejected the idea that these views were mutually exclusive. These decisions allowed individuals to carry certain weapons for self-defense including those useful for military service, like revolvers, while banning certain weapons like derringers, stilettos, and Bowie Knives that could be concealed $;^{58}$ they also, for the most part, upheld bans outlawing the public carrying of concealed weapons. ${ }^{59}$

In his article, Yassky creates a false dichotomy. The Second Amendment has to guarantee either a personal right of self-defense or a right bound up with obligations to perform, at least part time, military service for "collective" selfdefense. He ignores a third possibility that Don Kates has explored: that the Framer's vision for the universal militia-a collection of citizen-soldiers coming to the defense of each other, or the state, against invasion or usurpation-was merely the widely acknowledged right-obligation, even-of personal self-defense, against criminals for instance, writ large. ${ }^{60}$

\section{$\mathrm{V}$ \\ CONCLUSION}

Despite a spirited effort to rehabilitate Miller's treatment at the hands of the lower federal courts, Yassky falls short. His reading of Miller is not persuasive. Moreover, his account fails to take into consideration the arguments that were not adopted by the Court in rendering the Miller decision. From the prospective of gun control proponents, Miller is, at best, agnostic on the question of the Second Amendment's guarantee of an individual right. When, however, the decision is read in context, recognizing that the government was the only side

142, 145-46 (1986) ("[I]t should be clear that reasonable gun controls are no more foreclosed by the second amendment than is reasonable regulation of speech by the first amendment.").

58. E.g., Aymette v. State, 21 Tenn. 154, 158-59 (1842) (upholding statute prohibiting the wearing of concealed knives; stating that the arms protected by the Tennessee Constitution "are such as are usually employed in civilized warfare, and that constitute the ordinary military equipment.... They need not [secure] the use of those weapons that are usually employed in private broils, and which are efficient only in the hands of the robber and the assassin."). But see Andrews v. State, 50 Tenn. 165, 187-88 (1871) (striking down statute prohibiting carrying of "pocket pistols," whether concealed or not). It is worth noting that Miller specifically cited Aymette in support of its distinction between weapons with military utility and those without. Miller, 307 U.S. at 178.

59. See David B. Kopel, The Second Amendment in the Nineteenth Century, 1998 B.Y.U. L. REV. $1359,1432-33$ ("The majority of state courts in the nineteenth century upheld restrictions on the carrying of concealed weapons. Courts affirmed the rights of citizens to carry firearms openly for protection but held that concealed carry could be regulated, or even banned, by the legislature.") (footnote omitted).

60. Don B. Kates, Jr., The Second Amendment and the Ideology of Self-Protection, 9 ConsT. COMMENT. 87 passim (1992). Yassky fails to mention that the members of the Reconstruction Congress had no problem finding in the Second Amendment a right to keep and bear arms solely for selfdefense-one unconnected with any military service. E.g., AKHIL REED AMAR, THE BILl OF RIGHTS: CREATION AND RECONSTRUCTION 257-67 (1998) (discussing Second Amendment rights as viewed by the Framers of the Fourteenth Amendment); STEPHEN P. HALBROOK, FreEDMEN, THE FOURTEENTH AMENDMENT, AND THE RIGHT TO BEAR ARMS 1866-1876 (1998). 
arguing the case and that many of its main arguments were apparently rejected, or at least not adopted, by the Court, the decision begins to look more hospitable to a Standard Model reading.

What is clear from reading Miller is that what Yassky perceives as a "failure of the courts" is not a failure to recognize a constitutional moment, but rather a failure at a more basic level: the failure to read Miller carefully and apply it as they would any other somewhat vague Supreme Court decision. Instead, lower court judges have invoked the Supreme Court's recognized authority to "declare what the law is" to silence judicial dialogue; implicit in their opinions is the feeling that the Second Amendment ought not to exist. Yassky may be correct that judges had a hard time finding a place for the right after the New Deal, ${ }^{61}$ or that a fundamental alteration in national defense policy made it difficult to account for the reference to a "militia" being "necessary for the security of a free state," ${ }^{2}$ but that is no warrant for a continued attempt to read the Second Amendment out of the Bill of Rights. Or even out of Miller.

61. Yassky, supra note 3, at 663.

62. Id. at 598-610, 629-44. 